\title{
Across The World Secondary Schools Curriculum Based on The Scientific Approach
}

\author{
Budi Handoyo \\ Department of Geography \\ Faculty of Social Science \\ State University of Malang \\ Malang, Indonesia \\ Ach. Amirudin \\ Department of Geography \\ Faculty of Social Science \\ State University of Malang \\ Malang, Indonesia \\ Hadi Soekamto \\ Department of Geography \\ Faculty of Social Science \\ State University of Malang \\ Malang, Indonesia
}

Coressponding email: budi.handoyo.fis@um.ac.id

\begin{abstract}
Changing of the national curriculum in order to improve the quality of education being undertaken by the Ministry of Education and Culture of the Republic of Indonesia. In the geography, changing of the secondary curriculum was conducted at the content and learning process standard by implementing geographical skills and scientific approach. The purpose of this research was to analysis geographical skills of the geographic secondary school curriculum across the world based on the scientific approach. The study was designed by using a qualitative method which was conducted on July up to August 2016. The research object was the geographic skills of the junior school of the United State of America, United Kingdom, Australia, New Zeland, Singapore, and Indonesia. Data were collected by the document method which consists of the geographical skills content from the six countries. The analysis was conducted by comparing the geographical skills contents with the steps of the scientific approach. The research results showed that: (1) the geographical skills of the secondary curriculum of America, United Kingdom, Australia, and Singapore has a relevant pattern with the skills of the scientific approach; (2) the geographical skills of the secondary curriculum of New Zeland and Indonesia has quite relevant pattern with the skills of the scientific approach. (3) There is no geographical skills of the secondary curriculum across the world that do not relevant with the skills of the scientific approach. Based on the research finding and discussion were suggested that the geographical skills pattern of the national curriculum 2013 was needed to be developed in order to suitable with scientific approach.
\end{abstract}

Keywords-Geographical Skills, Scientific approach, Curriculum-Changing

\section{INTRODUCTION}

Changing the Curriculum 2006 to 2013 has been conducted by the Ministry of Education and Culture Republic of Indonesia in order to improve the quality of graduation. In the new curriculum 2013, there are four aspects have been changed in improving the standard of education. The fourth aspects are graduation standard, content, process, and evaluation (Permendiknas 32 Tahun 2013, 22, 23, and 24 Tahun 2016). The content standard consists of skill competencies, besides spiritual competence, social, and knowledge, and on the process standard use scientific approach as a main learning method. So, at the all of the subject matters must implement skills competency and scientific method as a part of learning.

Geographical skills is one of geography education goals, besides knowledge and attitude. It is not only related to the ability of geographic asking questions, collecting and analyzing data, presenting and communicating but also in terms of the broader aspects of the thinking skills to understand the earth and human activities (GNIP, 2012; Riter 2006). Therefore, the geographical skills has an important function, not only in geography education, but also in the general 
environment education. One of them is learning in understanding the environmental problems, social, cultural, economic, political in the global era (Reinfried \& Hertig, 2012; and Butt, et al. 2006).

The National Geographic and Improvement Project (2012) stated that geographical skills provide the necessary tools and techniques for us to think geographically. They are central to geography's distinctive approach to understanding Earth's physical and human patterns and processes. Geographic skills are used in making decisions important to everyday lifewhere to buy or rent a home; where to get a job; how to get to work or to a friend's house; and where to shop, vacation, or go to school. All of these decisions involve the ability to acquire, arrange, and use geographic information. Daily decisions and community activities are linked to thinking systematically and spatially about environmental and societal issues.

The statement indicates that the geographical skills have many uses. There are at least six usages of the geographical skills, namely: (1) as a frame of reference to think geographically; (2) make decisions in everyday life, such as where to buy or rent a home, place of work, shopping, vacation, and school; (3) take daily decisions and community activities related to think systematically and spatial issues and the social environment, such as where to place the industries, schools, and residential areas; (4) acquire geographic data for business and government in the use of resources or international trade with the placement of the best locations, such as the location of regional airports and supermarkets; (5) helps people make reasoned political decisions, such as foreign affairs and international economic policy or zoning on local land; (6) collects and analyzes information to a conclusion, and make a plan of action.

Since the 1980s, the importance of geographical skills that have been expressed by experts of geography education. For example Reinfried \& Hertig (2012) suggest that geography at primary and secondary schools plays an essential role in providing the learners the ability to develop critical thinking skills in order to comprehend the word. Such thinking skills are concerned with learning how to investigate and answer question referring to the relationships of human societies with space and the relationships between different human societies across space. The essence of the statement suggested that geography education in primary and secondary schools play an important role in providing students the ability to develop critical thinking skills in understanding the world. The thinking skills related to learn how to research and answer questions to the public with a spatial environment.

In the road map of the American Geography Education for the XXI century also noted the importance of geographical skills. The roadmap stated:

everyone in modern society faces personal decisions that require geographic reasoning... such as where to live and how to travel from place to place, can have an enormous impact on one's life.... which products to buy and how to dispose of them. .... In this era of such global challenges as ethnic and religious conflict, growing populations in poverty, increasing competition for limited natural resources, and degradation of the environment, it is essential that all members of society be prepared to make these decisions (Bednarz, dkk. 2013).

The statement indicates that the road map of the geographical skills are very useful for people in everyday activities. For practical activities, such as making decisions where their life, travel from one place to another, and residents will definitely need geographical skills. Similarly, in the complex such as understanding the conflict between religion and ethnicity, growth the poor, competition for natural resources, environmental degradation, they also need the geographical skills. Thus, geographical skills have an important function for students (Handoyo, 2015).

Mastery geographical skills necessary for students to understand the problems of the geosphere in the Earth's surface that is complex increasingly, and can act wisely to enable the sustainable life. In addition, the acquisition of geographical skill can also expand an access to students in understanding the process of human-environment linkages society, and changes in space as an impact of the activities of individuals or groups that continued development from time to time (Handoyo, 2015).

Besides containing geographical skills, the new Curriculum 2013 also includes a scientific approach for learning processes. In the scientific approach, there are five skills that is fostered in learning. The fifth skills are observation, asking, experiment, association, and communication (Kurikulum, 2013). The fifth skills become a reference for planning and implementing which is composed and implemented by the subject teachers. The Scientific method is an attempt to understand the world through observation, analysis and deduction. It requires a trust in empirical evidence (our knowledge comes from our senses). The Scientific method is observing (watch), hypothesis (make a theory), experiment (try it out), verification (testing the theory with further experiments). It is based on fact and evidence.

The advantages of the scientific method are: (1) it is based on empirical evidence, (2) it is proof and verification, (3) found by reasoning and observation, (4) reliable at finding the truth, (5) scientists are impartial, and cautious with theories that are backed up. In a nutshell, the scientific method teaches the brain to logically examine and process all the information it receives. It requires that one observes and tests before making a statement of fact. This is the main method scientists use when asking and answering questions.

A scientist follows the same steps each time he employs the scientific method. They are: ask a question, do some research, formulate a hypothesis, test with experimentation, record and analyze observations and results, and draw a conclusion. The scientific method is important for the homeschooler to teach because it is a fundamental process in science, but the benefits of teaching your students this process 
will go beyond their science class. Not only scientific method is integral to understanding science, but also a technique that trains the student how to answer a question in a logical manner. This method teach the student to analyze and process the information who are receiving. It trains the brain to logically examine and process all the information it receives.

Due to the geographical skills and scientific approach is very important, many countries in the world that contain both these aspects in their curriculum. The developed and developing countries, such as USA, UK, Australia, New Zealand, Singapore, and Indonesia have established clearly the contents of geographical skills and scientific approaches. The problem is how far the relevant pattern of the geographical skills of each country to the scientific approach.

\section{METHOD}

The study was designed by using a qualitative method which was conducted on July up to August 2016. The research object was the geographic skills of the junior school of the United State of America, United Kingdom, Australia, New Zeland, Singapore, and Indonesia. Data were collected by the document method which consist of the geographical skills content from the IGU and six countries across the world. The analysis was conducted by comparing the geographical skills contents with the steps of the scientific approach. Criteria which is used of the relevance is follows: Relevance: when the geographical skills covered in the scientific approach. Quite relevant: if the geographical skills does not meet all the skills of the scientific approach. Not relevant: when there is no geographical skills covered in the scientific approach.

\section{FINDINGS AND DISCUSSION}

The results of the research show that there is a different geographical skills of the country across the world. The geographical skills of the each country can be expressed as follows. First, geographical skills of the United of America (2012) "is posing the geographic question, acquiring geographic information, organizing geographic information, analyzing geographic information, answering the question and designing solution, communicating geographic information" (National Endowment For The Humanities, 2012).

Second, geographical skills the United Kingdom is "build on their knowledge of globes, maps and atlases and apply and develop this knowledge routinely in the classroom and in the field; interpret Ordnance Survey maps in the classroom and the field, including using grid references and scale, topographical and other thematic mapping, and aerial and satellite photographs; use Geographical Information Systems (GIS) to view, analyse and interpret places and data; use fieldwork in contrasting locations to collect, analyse and draw conclusions from geographical data, using multiple sources of increasingly complex information" (Departement for Education, 2013).
Third, geographical skills of Australia is "identifying an issue or problem and developing geographical questions to investigate the issue or find an answer to the problem; collecting information from primary and/or secondary sources, recording the information, evaluating it for reliability and bias, and representing it in a variety of forms; making sense of information gathered by identifying order, diversity, trends, patterns, anomalies, generalisations and cause-and-effect relationships, using quantitative and qualitative methods appropriate to the type of inquiry and developing conclusions. It also involves interpreting the results of this analysis and developing conclusions; communicating the results of investigations using combinations of methods (written, oral, audio, graphical, visual and mapping) appropriate to the subject matter, purpose and audience; reflecting on the findings of the investigation; what has been learned; the process and effectiveness of the inquiry; and proposing actions that consider environmental, economic and social factors (Education Ministry of Australia, 2013).

Forth, geographical Skills of Singapura is "identify and classify physical and human features of the environment; observe, collect and record geographic information from both primary and secondary sources;interpret maps, tables, graphs, photographs and fieldwork data; and organize and present information in a coherent manner" (Education Ministry of Singapore, 2006).

Fifth, geographical Skills of New Zeland is "geographic skills fall into several categories: geographic resource interpretation, geographic resource construction skills, communication skills, social skills, and fieldwork. Geographic resource interpretation skills include: using maps, photographs, diagrams, cartoons, images, statistics, keys, graphs, text, models, internet, speeches, surveys, films, TV, video clips and GIS to explain geographic information. Geographic resource construction skills include: drawing sketch and précis maps, diagrams, constructing models, taking photographs or drawing pictures, cartoons, constructing graphs, tables and using GIS layering to present specific geographic information. Communication skills include: being able to present geographic information in a variety of forms such as essays, paragraphs, poems, visuals, models, films, PowerPoint presentations, speeches, games, puzzles, blogs and graphic organizers. Social skills include: being able to work in groups and being empathetic, appreciating different values, perspectives and viewpoints on different aspects of geography, establishing and justifying personal value positions, contributing and participating in the community. Fieldwork skills include: being able to gather information from the field using a variety of techniques such as surveying, questionnaires, field sketching, measuring, photographing, interviewing and observing (Education Ministry of New Zeland, tanpa tahun).

Sixth, geographical skills of Indonesia (2013) is "presentation of data and facts Indonesia's geographical conditions, the supply of industrial materials, and alternative energy in the form of narrative, tables, maps, graphs, or maps and concept. (2) information processing dynamics of planet 
Earth as a living space and presenting it in the form of narration and illustrations. (3) presentation of examples of the application of basic knowledge of geography, geography research measures; mitigation and air-way adaptation to natural disasters; prudent action on the utilization of natural resources; the results of analysis of the application of the basics of mapping and Geographic Information System (GIS) in everyday life. (4) presentation of the results of the analysis of the nation's cultural diversity; the relationship between man and his environment as the influence of the dynamics of the lithosphere, atmosphere, hydrosphere in narrative form, tables, charts, graphs, illustrations, and or a concept map. (5) with the interpretation of remote sensing imagery. (6) presentation of the report and the observations of the dynamics of population problems and human resources in Indonesia. (7) comparison of patterns of distribution and spatial interaction between village and city using thematic maps. (8) the drafting of the mutually beneficial cooperation between developed countries and developing countries. (9) communicating the distribution of flora and fauna, national mining goods in narrative form, tables, maps, charts, and or concept maps.

Based on the geographical skills above can be revealed that content of the geography skills from one country to another is different. There are several countries have complex geographical skills, but there are also several countries have simple geographical skills. In the next table be presented the position of geographical skills to scientific approach.

TABLE 1 RELEVANCE OF THE GEOGRAPHICAL SKILLS TO SCIENTIFIC APPROACH

\begin{tabular}{|c|c|c|c|c|c|}
\hline \multirow{2}{*}{ Countries } & \multicolumn{5}{|c|}{ Scientific Approach } \\
\hline & Observation & Question & Experiment & Association & Communication \\
\hline Amerika & Fieldwork & $\begin{array}{l}\text { posing } \\
\text { geographic } \\
\text { question }\end{array}$ & $\begin{array}{ll}\text { acquiring } \\
\text { information }\end{array}$ & $\begin{array}{lr}\text { organizing } & \text { geographic } \\
\text { information, } & \text { analyzing } \\
\text { geographic information }\end{array}$ & $\begin{array}{lcr}\text { answering question and } & \text { designing } \\
\text { solution, communicating } \\
\text { information }\end{array}$ \\
\hline $\begin{array}{l}\text { United } \\
\text { Kingdom }\end{array}$ & Fieldwork & $\begin{array}{l}\text { Formulated } \\
\text { problem }\end{array}$ & fieldwork & Using GIS & presenting conclusion. \\
\hline Australia & Fieldwork & $\begin{array}{l}\text { Identifying } \\
\text { and } \\
\text { developing } \\
\text { problem }\end{array}$ & Collecting data & Analysing data & communicating data and reflecting \\
\hline Singapura & Observation & $\begin{array}{l}\text { Identifying } \\
\text { problem }\end{array}$ & Collecting data & $\begin{array}{lll}\begin{array}{l}\text { Organizing } \\
\text { analysing }\end{array} & \text { data } & \text { and } \\
\end{array}$ & Presenting information \\
\hline New Zealand & $\begin{array}{l}\text { Geographic resource } \\
\text { interpretation skills }\end{array}$ & - & Fieldwork skills & $\begin{array}{l}\text { Composing geographic } \\
\text { resources }\end{array}$ & Communication skills \\
\hline Indonesia & Observation & & Collecting data & $\begin{array}{lll}\begin{array}{l}\text { Organizing } \\
\text { analysing }\end{array} & \text { data } & \text { and } \\
\end{array}$ & Presenting results \\
\hline
\end{tabular}

Table 1 illustrates the geographical skills which is available at the secondary school curriculum several countries in the world. First, there are some similarities contents of geographical skills from country to country, but also there are differences content among their geographical skills. Almost all the countries install the skills of data collection, data organization, data analysis, and communication. Second, geographical skills include technical skills and higher level thinking skills. Technical skills are skills for data collection, such as measurements, interviews, and observations. And highlevel thinking skills, such as organizing data in the form of tables, charts and diagram; analyzing data with a variety of methods of analysis, such as pattern analysis, structural, temporal, interaction, and so on. Third, some countries have a similar pattern of the geographic skills to the skills of the scientific approach, such as the United State of America, Australia, the UK, Singapore. Some other countries have a pattern of geographic skills rather approach the skills of scientific approach, such as New Zeland and Indonesia. Fourth, the development direction geography skills increasingly focused on scientific skills, i.e observation, question, collecting data, organizing data, analysis data, and communicating result.

The research finding shows that the geographical skills of the secondary curriculum of America, United Kingdom, Australia, and Singapore has a relevant pattern with the skills of the scientific approach, and geographical skills of New Zeland and Indonesia is quite relevant with the scientific skills. There is no geographical skills of the secondary curriculum across the world that do not relevant with the scientific approach.

The result findings indicate that the geographical skills were dynamic. The dynamics can be seen from the efforts of each country to develop skills of geographic based on the demands of curriculum, characteristic student and development era. The results finding Handoyo (2015) showed that the national education of America has changed geographical skills on 2012, due to the geographical skills could not follow the development of era. The skills which developed were skills of 
communicating information geography. Similarly, Indonesia also has developed geographical skills on the curriculum 2013. In the previous curriculum (Curriculum 2006) there is no geographical skills explicitly. However, on the curriculum 2013 geographical skills can be seen explicitly that achieved by students at each lesson.

Moreover, the direction of geographical skills development today looks increasingly with scientific skills. The skills, developing toward research skills, such as problem identification, problem formulation, data collection, data organization, data analysis and communication of results. The development of these skills show that geographical skills and scientific skills equally has an important function to cultivate students' competency skills in understanding the phenomenon in a more comprehensive and authentic. For example the development direction of Australian secondary school geographical skills to the geographical inquiry. And the Education Ministry of Australia (2013) stated: geographical Inquiry is a process by which students learn about and deepen their understanding of geography. It involves individual or group investigations that start with geographical questions and proceed through the collection, evaluation, analysis and interpretation of information to the development of conclusions and proposals for actions.

When geographical skills leads to the inquiry, it has features as follows: (1) inquiry geography is a process not result; (2) involving the investigation of individuals and groups; (3) the investigation activity begins by asking the question of geography, followed activities of collection, evaluation, and interpretation of data/information; (4) making inferences; and (5) propose an action plan. Thus, to gain mastery of geographical skills required learning that prioritizes the process and not the result.

In the application of geographical skills that looks inquiry there are several principles that can be used as an academic basic. Application of geographic inquiry in this study is based on the five general principles. Using these principles oriented toward intellectual development, interaction, and asking, learn to think, and openness (Sanjaya, 2008). Each principle is described briefly as follows. First, oriented on intellectual development. The main purpose of inquiry strategy is developing the ability to think the extent to which students move search and find something and not limited mastery of the material. Second, the interaction. Teachers do not put their self as a learning resource, but regulating the interactions so that students can develop the capacity to think. Third, ask. Teachers act as the questioner, as the student's ability to answer questions is part of the thinking process. Fourth, learn to think. Learning is not just recalling some facts, but also the thinking process. Fifth, openness. The task of the teacher is to provide space to provide opportunities for students to develop hypotheses and openly validate the hypothesis that advocate.

In addition the fifth principles, geographical skills that looks inquiry is based on two theories of education. The second educational theory are cognitive development theory of
Piaget and Bruner. In the cognitive theory of Piaget stated that the cognitive development of children at the age of 11-15 years entered a period of formal operations. At this age children can begin to think abstractly and logically. The process of organizational and intellectual adaptation at this period was influenced by the schemata, assimilation, accommodation, and balance.

Schemata is a set of concepts that exist in the child. Assimilation is an event to match a new information with old information that has been owned child. Accommodation is a phase match between the new and old information previously not suitable then compared and adjusted with old information. The balance is the last phase the students get to know the new information obtained (McLeod, 2009; Silverthorn, 1999). Thus in this period, the child is ready to be involved in the abstract problems. This means that students are ready to understand and apply geographical inquiry including: observations to obtain data; analysis of data obtained from observation, presented data and analysis results with tables, graphs and narrative; and to predict what will happen next.

In Bruner theory stated that the child's intellectual development follows three sequential stages. The third stage of intellectual development is enaktif, iconic and symbolic (Nuryadi, 2013). Enaktif At this stage, all the attention of the child depends on his response. The iconic stage, the child's thinking patterns depending on the sensory organization. Symbolic stage, the child has to have full understanding about something so that they are able to express his opinion with the language.

Accordance with the theory, children at school age has entered the stage of the symbolic. Therefore, the implications of the theory is a confront student to the problem. Based on the experience, child will try to adjust or reorganize the structures of ideas in order to achieve a balance in his mind. Thus, in a geography lesson, students need to be faced with the problems geosphere is the subject of discussion. In groups, students are involved to identify and define problems, collect data, analyze the data, presented data and analytical results, and make predictions.

Based on the review of these theories, it can be argued that there are three factors that allegedly having an effect on the achievement of geographic inquiry. The third factor is the intellectual, academic ability, and effective learning. Intelligence is a potential intellectual to think or reason, solve problems, and communicate. Academic ability is the skill to think conceptually and theoretically based on factual knowledge, conceptual, procedural, and metacognition. The effectiveness of learning is an instructional system performance in order to optimize the potential of the intellectual and academic abilities. Thus a good learning plan which is implemented consistently assumed to optimize the intellectual and academic ability in obtaining geographic inquiry.

Empirical studies related to the determinant factor of the geography skills are still very limited. The study lasted for 
learning geography is more concentrated in geographic knowledge, especially knowledge of conceptual, factual, and metacognition. Conceptual and factual knowledge are widely studied geography relating to learning outcomes, such as knowledge of the lithosphere, atmosphere and hydrosphere. Metacognitive knowledge is widely studied is the problem solving skills, critical thinking, analysis, and creative.

The geographical skills development in accordance with the direction of the International Geography Union. Geographical skills has a broad scope accordance with the development era. As presented by the IGU (2009) that geographical skill is using verbal, quantitative and symbolic data forms such as text, pictures, graphs tables, diagrams and maps; practising such methods as field observation and mapping, interviewing people interpreting secondary resources and applying statistics; and using communication, thinking, practical and social skills to explore geographical topics at a range of scales from local to international. Such a process of inquiry will encourage students to: identify questions and issues; collect and structure information; process data; interpret data; evaluate data; develop generalisations; make judgments; make decisions; solve problems; work cooperatively in team situations, and behave consistently with declared attitudes.

\section{CONCLUSION}

Based on the result of the research and discussion can be concluded that: (1) the geographical skills of the secondary curriculum of the united State of America, Australia, United Kingdom, and Singapore were relevant with the skills pattern of the scientific approach; (2) the geographical skills of the secondary curriculum of the Indonesia and New Zeland were quite relevant with the skills pattern of the scientific approach. (3) there is no geographical skills of the secondary curriculum across the world that do not relevant with the scientific approach. Based on the research finding and discussion were suggested that the geographical skills of the national curriculum 2013 was needed to be developed in order to suitable with scientific approach.

\section{REFERENCES}

[1] Bednarz, Sarah Witham., Heffron, Susan., Tu Huynh, Niem (editor) 2013. A Road Map for 21st Century Geography Education Geography Education Research. Washington DC: Association of American Geographers, the national geographic society, (online), (http://education.national.geographic.com/media/file/ngs_roadmapconce pt_gerc_07.pdf), accessed 14 September 2013.

[2] Butt, G., Hermer, M., \& Houtsonen, L. 2006. Geography in Europe. Dalam J. Lidstone \& M.William (Eds.), Changing Education in a Chaging World Past Experience, Current Trends and Future Challenges (hlm.93-106) Dordrecht: Springer.

[3] Departement for Education. 2013. Geography Programmes of Study: Key Stage 3 National Curriculum in England. (online) (https://www.gov.uk/government/uploads/system/uploads/attachment_d ata/file/239087/secondary_national_curriculum_-_Geography.pdf), diakses 16 April 2013.
[4] Education Manastry of Australia. 2013. Australian Curriculum, (online), (http://www.australiancurriculum.edu.au/humanities-andsocial-sciences/geography/content-structure), diakses 25 April 2013.

[5] Education Ministry of Singapore, 2006) Singapore Curriculum, (online), (http://www.singaporecurriculum.edu.au/humanities-andsocial-sciences/geography/content-structure), accessed 25 April 2013.

[6] Education Ministry of Australia Education Ministry of Australia. 2013 Australian Curriculum, (online), (http://www.australiancurriculum.edu.au/humanities-and-socialsciences/geography/content-structure), accessed 25 April 2013., 2013

[7] Gardner, Howard. 1999. Intelligence Reframed: Multiple Intelligences for 21 st Century. New York: Basic Book.

[8] GENIP. 2012. Geography For Life: National Geography Standards, Second Edition Geographic Skills Provide the Necessary Tools and Techniques for us to Think Geographically, (online), (http://www.nationalgeographic.org/education/national-geographystandards/) accessed 13 September 2013

[9] Geography Education National Implementation Project (GENIP) - a consortium of the Association of American Geographers (AAG), the American Geographical Society (AGS), the National Council for Geographic Education (NCGE), the National Geographic Society (NGS). 2012. Geography for Life: National Geography Standards, Second Edition, an update of the 1994 publication, (online), (http://education.nationalgeographic.com/ education /nationalstandards/geographic-perspectives/?ar_a=1), accessed 7 January 2013.

[10] Gerber, Rod. Tanpa tahun. Geographical Education. Geography. Vol. 1. Faculty of education, health and Professional Studies, University of New England, Armidale, Australis, (Online), (http://www.eolss.net/sample-chapters /c01/ E6-14-01-03.pdf), accessed 12 September 2012

[11] Handoyo. Budi. 2015. Pengaruh Group Investigation dan Kecerdasan Intelektual terhadap Keterampilan Geografi. Disertation. UM. Tidak diterbitkan.

[12] International Bachelorate. tanpa tahun. Aims and Objectives of $I B$ Geography, (Online), (http://www.angelfire.com/ga2/ibgeography/aimsobjectives.html), accessed 20 September 2012.

[13] The International Geographic Union. The Contribution Of Geography To Education, (Online), (http://www.igu-cge.org/charters_1.htm), accessed 10 September 2013.

[14] McLeod, Saul. 2007. Jean piaget. (online), (http://www.simplypsychology.org/ piaget.html), accessed 13 Juli 2015.

[15] McLeod, Saul. 2009. Lev Vygotsky. (Online), (http://www.simplypsychology.org/vygotsky.html), accessed 20 Juli 2013.

[16] Ministry of Education. 2006. Curriculum Planning and Development: Geography Syllabus in Singapore, (online), (http://www.moe.gov.sg/education/syllabuses/humanities/files/geograph y-lower-secondary-2006.pdf), diakses 16 April 2013.

[17] National Erdowment for the Humanities. 1912. Geography for Life: National Geography Standard $2^{\text {nd }}$ Edition 2012, Washington, DC: Departement of Education.

[18] Nuryadi. 2013. Aplikasi Teori Bruner Dalam Pembelajaran Matematika Di Tingkat SD Menentukan Rumus Luas Daerah Persegi Panjang dan Luas Segitiga dengan Model Pembelajaran Penemuan Terbimbing. (Online), (C:IUsersLListyolDownloads\Documentslaplikasi-teori-brunerdalam-pembelajaran-matematika-di-tingkat-sd.pdf Error! Hyperlink reference not valid.) diakses 20 Juli 2014. 
[19] Peraturan Menteri Pendidikan dan Kebudayaan Republik Indonesia Nomor 103 Tahun 2014 Tentang Pembelajaran Pada Pendidikan Dasar
Dan
Pendidikan
Menengah
(online)

(https://akhmadsudrajat.files.wordpress.com/2014/11/permendikbud-no103-tahun-2014.pdf.

[20] Peraturan Pemerintah Republik Indonesia Nomor 32 Tahun 2013 Tentang Perubahan Atas Peraturan Pemerintah Nomor 19 Tahun 2005 Tentang Standar Nasional Pendidikan, (online), (http://sindiker.dikti.go.id/dok/PP/PP\%2015\%202015\%20standard\%20n asional\% 20pendidikan\%20tinggi.pdf), diakses 14 Januari 2013.

[21] Reinfried, Sibille \& Hertig, Philippe. Tanpa tahun. Geographical Education: How Human-Environment-Society Processe Work, (online), (http://www.eolss. net /sample-chapters/c01/e6-06b-46.pdf), diakses 24 Maret 2012.

[22] Sanjaya, W. 2006. Strategi Pembelajaran Berorientasi Standar Proses Pendidikan. Jakarta: Kencana Prenada Media.

[23] Silverthorn, p. 1999. Jean Piaget's Theory of Development. (online), (https://pdfs.semanticscholar.org/2ac7/4db0f161a01cc6c6aa0d0d919d3d 2cff397f.pdf), accessed 19 maret 2013. 